\title{
Wineries in communication with holy mountains
}

\section{Winiarnie w relacji ze świętymi górami}

\begin{abstract}
The contemporary wine architecture built in the sacral landscape, their interaction and philosophy are the particular focus of this paper. The paper presents two recently completed winery complexes in Hungary, the Bazaltbor Winery (2010) and the St. Ilona Winery (2013). Both of them are built at the foot of the volcanic hills (Badacsony, Somló), which "witness" the reunion of man and nature through over two thousand years of wine culture. The research goal is to discover the architects' and landscape architects' intentions, how did they face the challenge? Did they subordinate the winery to the landscape, did they copy the shape of the natural landscape, did they hide the building under the earth or did they re-interpret the whole situation? Did they react to the sacrality of the place?
\end{abstract}

Keywords: sacral landscape, sacrality of wine, wine architecture

\section{Streszczenie}

Tematem artykułu jest współczesna architektura wina zbudowana w krajobrazie sakralnym - jej interakcja i filozofia. W artykule przedstawiono dwa ostatnio ukończone kompleksy winiarskie na Węgrzech, Winiarnię Bazaltbor (2010) i Winiarnię Świętej llony (2013). Oba są zbudowane u podnóża wulkanicznych wzgórz (Badacsony, Somló), które „świadczą” o zjednoczeniu człowieka i natury przez ponad dwa tysiące lat kultury wina. Celem badawczym jest odkrycie zamiarów architektów i architektów krajobrazu - w jaki sposób stawili czoła wyzwaniu? Czy podporządkowali winiarnię krajobrazowi, czy skopiowali kształt naturalnego krajobrazu, czy ukryli budynek pod ziemią, czy też ponownie zinterpretowali całą sytuację? Czy zareagowali na sakralność tego miejsca?

Słowa kluczowe: krajobraz sakralny, sakralność wina, architektura wina 


\section{SACRALITY OF WINE}

After all, two will remain, God and the wine ${ }^{1}$

The subject of wine touches on a huge range of academic disciplines, from natural sciences (chemistry, biochemistry, plant biology, even human biology and psychology) through humanities (history, geography) and social sciences (economics, sociology) to business management, and areas of philosophy (especially aesthetics and the philosophy of language). Although interest in wine is almost as old as humanity, it is only perhaps since the late twentieth century that 'wine studies' - looking at the place of wine in society as a whole - has emerged as a significant field of research and teaching ${ }^{2}$.

Besides its nutritional value, wine also has cultural and symbolic meanings, such as sacrality, joy, and sharing. Wine, as a representative of the divine, sacred spirituality also determined by traditions, has been present in the mind of humanity for several millennia ${ }^{3}$.

The references to the symbolic and cultural significance of wine and viticulture can be found in literary works as epics, histories and geographies, specific agricultural treatises, and miscellaneous poems and religious, which generally date from the period after about 500 BC. For instance, in the great epic poems, such as the Sumerian Epic of Gilgamesh and Homer's Odyssey, dealing with tales of heroes, and the relationships between the gods and humanity, tell us much about the religious significance of wine [...]. The Historical and geographical works, such as The Histories of Herodotus dating from the fifth century BC, and Strabo's Geography dating mostly from the early first century AD, also provide a wealth of material concerning the production, consumption, and redistribution of wine. The Roman agricultural treatises, such as the De Agricultura of Cato (234-149 BC), and Columella's Res Rusticae written in $65 \mathrm{AD}$, provide a wealth of information concerning all aspects of the cultivation of vines and the production of wine. To these must also be added the vast corpus of religious writings, including perhaps most importantly the Bible, which provides a major source for our understanding of the Jewish and Christian symbolism of wine and the vine ${ }^{4}$. For the Jews, wine is a symbol of blessing, joy, and wealth, and it's a crucial part of key Shabbat rituals, while to Christians, it is not only a symbol, but it is a part of God. Drinking wine during the Eucharist conveys a message of universal love and provides access to eternal life. By commanding, "Do this in remembrance of me," Jesus ensured that wine will always be at the heart of the mystery of his presence. The Holy Grail further emphasizes to Christians that wine is the symbol of the blood shed for them. Of all religions, Christianity most firmly positions wine as an essential embodiment of its message ${ }^{5}$. In Hippocrates of Cos's (460-370 BC) Regimen in Acute Diseases, Hippocrates identifies how to treat ailing patients, describing many healing uses of wine, including its use as a wound dressing, as a nourishing dietary drink, as a cooling agent for fevers and as a diuretic. Also, the significance of wine is charted in the philosophical musings of many great classical philosophers such as 
Plato, Virgil and Horace ${ }^{6}$. These literary sources provide a wealth of evidence concerning the emergence of viticulture and winemaking for thousands of years ago, and their symbolic and cultural role in the ideology of the peoples. Wine has been a sign of wealth, power, and happiness. It was cherished and used widely in sacred (religious) and secular (non-spiritual) contexts to mark events, occasions, rituals, celebrations and in the treatment of patients through the ages. As well, it was used as a marker of history, tradition, local identity and spirituality. According to two of the world's leading wine writers: There is no other product on earth, agricultural or industrial, where the value is as directly and precisely linked to where it grows and is made. Only wine goes to market with the name of a field, a farm, or at least a county'.

\section{WINE ARCHITECTURE AND LANDSCAPE}

Nowadays, wine architecture has the same imagery as wine, where the context, rituality and vague atmosphere are some common features of both. Wineries are like religious buildings where people go in droves on alcoholic pilgrimages. Moreover, the natural elements are important to utilize in an architectural emotion. The sun, land, stone, soil, the forces that contribute to the ripening of the wine, are presented in wine architecture to evoke a connection to nature. The relation between the territory and the built structure will be explored in this paper.

The most important communication for architectonic development is how the countryside can be built on, now and in the future, and how a new understanding of the symbiosis of nature and culture could be created ${ }^{8}$. The Hungarian contemporary wine architecture built in the sacral landscape, their communication and philosophy are the particular focus of this paper. Based on case studies, the aim of our research is to discover the architects' and landscape architects' intentions, how did they face the challenge? Did they subordinate the winery to the landscape, did they copy the shape of the natural landscape, did they hide the building under the earth or did they re-interpret the whole situation? Did they react to the sacrality of the place?

There were two criteria for the selection of case studies: their location and their architectural appreciation. We have selected two recently completed winery complexes from two wine districts which are known for their volcanic buttes. The case studies are widely published on websites and in periodicals. To carry out the study, we relied on written materials (designers' texts, architectural critics' reviews), photos and on the detailed, onsite analysis of the selected buildings. 


\subsection{SACRAL LANDSCAPE}

Usually, the term 'sacral landscape' is construed as a subtype of a landscape where the spatial organisation of material and immaterial objects is conducive to experiencing sanctity. This is one of the oldest types of cultural landscape, remaining, for the most part, in an immaterial dimension. Depending on the region, its cultural development and the experience of the viewer, a sacral landscape can be any type of cultural landscape where sacrum is experienced and which becomes a place for outlook-related reflections, e.g. holy mountains, pilgrimage trails, locations sanctified by a religious event etc. The sacral landscape, developed over the centuries, includes not only the material domain in the form of numerous historic structures, monuments and other evidence of the religious development of the society, but also, to a large extent, the immaterial domain which manifests itself in the form of spiritual heritage, faith, traditions, customs or language ${ }^{9}$.

The north coast of Lake Balaton, the Balaton Uplands, includes areas under nature protection and cultural heritage protection, and as well as the areas under the protection of historic buildings and monuments. The significant natural treasures of the entire Balaton wine region are the picturesque surface forms of volcanic origin which provide a special and aesthetic landscape enhanced with a several-century-old viticulture and a folk architecture which lives on renewed. The volcanic mountains of the Balaton Highlands and on the nearby Small Plain have a special position: they testify to the height of the surface of the past. External forces cut off the softer rock area around them, but these peaks remained because the hard basement guard defended them from destruction. They are called "witness" mountains, which are guarding, showing, attesting to the old age. The natural gallery of volcanic and erosional phenomena has become a harmonic, humanized landscape of outstanding beauty in the wake of millennia-long human activity, and is considered a sacral landscape.

\section{TWO WINERIES}

A dozen countries in central and south-eastern Europe have been cultivating wine for centuries, but only a few of them are pursuing a progressive course in their vineyards and cellars/wineries to supplement their ancient traditions. One of these countries is Hungary, where wine is a major characteristic feature of its culture, history, and gastronomy. The new wineries are visual proof of the changes that have taken place since the 1990s (e.g. Hétszőlö winery (1992), Disznókő winery (1995), Oremus winery (1999-2000), Szent Donát winery (2001), Abbey Winery Pannonhalma (2003), Béres Winery (2003), Konyári Winery (2004), Füleky Winery (2010), Bazaltbor-Laposa Winery (2010), Kreinbacher-St.llona Winery (2013) etc.). According to the architects' description, alongside the physical requirements of a winery, they stress the building's relationship to the landscape and especially to the 
territory. To express the local tradition, history and the mystery of wine production, to shape spirituality and capturing the 'genius loci' of the landscape, seems to be the basic evaluation criteria for wine architecture. This aspect is even stronger in a region which comprises unique natural and cultural values and advanced wine growing and viticulture, based on the rare geodiversity of the cultivable areas, as in the case of the Balaton region.

The case study buildings are situated in a specially valued and protected cultural landscape. The Bazaltbor-Laposa Winery complex (2010, Architects Péter Kis and Bea Molnár, landscape architecture Bogner Studio) is settled in the Badacsony wine district - a part of the Balaton Highland National Park. It is an exclusive territory located in central Transdanubia and delimited by the taller Bakony range from the north and the lake from the south. This wine region, comprising 1600 ha, was named after the mountain Badacsony (438 m) - "standing as lord-paramount of the northern shore of the Lake"10. The vines are planted on the foothills, steep slopes, and terraces which are covered by a clay soil mixed with basalt debris. The Kreinbacher-St.Ilona Winery complex (2012-2014, Architect Dezső Ekler, landscape architecture Bojza Bt.) is located in the Nagy-Somló or "Greater Somló" wine district. The entire region consists of one longextinct volcanic hill and is Hungary's smallest wine region, which covers 690 ha of vines. It is situated in western Transdanubia, on the boundary between the Bakony Mountains, and the Marcal Basin, on the eastern periphery of the Little Plain. Most of the vines are planted on the slopes of Somló hill, which are covered by a loam mixed with basalt clast, and weathered volcanic tuff.

The Bazaltbor-Laposa Winery complex lies at the foot of the holy mountain, Badacsony and is surrounded by the basalt cliffs and stone screes, which emerge from the forested peak of the mountain, vineyards, retaining walls, press houses, and lake. The complex consists of a wine production facility, which lies at the foot of the hill, and a wine hotel, built later, higher up the slope (Fig. 1). The hotel, having an archetypal vineyard press-house form, includes also a catering, tasting, and wellness facilities and offers an extraordinary panorama of Lake Balaton, vineyards, and the winery. The winery, including the production facilities, cellar, and a visitor centre, has international popularity, it became the "Industrial Building of the Year 2010" in an international public vote organized by the Archdaily portal ${ }^{11}$. The building volume emerging from the hillside is created by the serpentine of repeated blocks of stylized forms of the typical local, pitched-roofs of press houses. The longitudinal axis of the building, which is bent several times, recalls the tectonics of the landscape: poured out and hardened lava (Fig. 2). The size of the winery exceeds local scales, even though three-quarters of the volume is submerged in the belly of the hill. The visible part of the blocks is homogeneous clad in prefabricated concrete facing panels with a slightly transformed pattern of grapevines climbing and twining around them. These panels are punctuated by the glazed areas covered in metal panels perforated with a similar pattern. 
The Kreinbacher-St. Ilona Winery complex lies at the foot of the volcanic hill, Somló and is surrounded by the vineyards, typical Hungarian buildings, and the basalt cliffs and stone screes which emerge from the forested peak of the mountain. The winery complex consists of four parts. Designed as individual buildings and completed in different periods, they are different in character, but their structures have much in common. The St. Ilona Winery was built as the first part of a major complex and includes the production facilities, cellars, and tasting room. The large part of the winery is hidden from view from the main road by an artificial hill, being visible just a cantilevered structure with a gabled roof, which protrudes from the body of the hill (Fig. 3). In the back, the building opens towards the mountain and the vineyards. The second part, the Kreinbacher Champagne winery, comprising the fermentation and processing areas, administrative offices and a spacious professional tasting room, is the twin brother of the St. Ilona winery and appears as if it were carved out of the latter's hill. The monolithic concrete masses evoke forms of geological forces with shapes of lava flows appearing in their layouts and forms of tectonic movements and lava tunnels appearing in their sections ${ }^{12}$. The third part of the complex is the Champagne maturing facility where the long-term storage, maturing and bottling take place. Its volume, influenced by the narrow plot allowed for the construction, represents another artificial hill. The visible elements are the longitudinal, darkgrey wall punctuated by the "bubble" windows and a cantilevered structure with the gabled roof (Fig. 4). The hotel, the last unit, employing the same architectural approaches as the adjacent buildings: it is a hill-house with a concrete structure and basaltic colours ${ }^{13}$. The long, mild curved shape of the building frames a cosy yard organized in terraces (Fig. 5). On the longitudinal sides are generous windows, which make the building communicative and offer a panoramic view of the surrounding landscape.

\section{INTENTIONS AND REFLECTIONS}

The architects of the Bazaltbor-Laposa Winery conducted intensive research before getting to work. They described their intentions in several articles published after the completion of the complex. According to the architects, in structuring and shaping the winery they took into consideration the geography, natural tectonic components of the site, and the neighbouring wine cellars ${ }^{14}$. "In the geometric model two basic elements - the symmetric gable, closed roof abstraction of the press house and the hexagonal shaped idealized cross section of the basalt pillars-layers - connect together into a new system, which at the same time is also a reminder of both references. The basic elements - as the basalt bands that erupted to the surface run freely, in any direction where there are no obstacles; sometimes separating, sometimes joining. The dimensions of the geometrical basic elements (cross sections) are variable, thus flowing into each other, in places rising from the soil and providing a distorted surface on the roof" - they explain the origin of the distorted line of the processing house ${ }^{15}$. The nature and 
the basalt of the mountain here manifested in the basalt bounds once going down from the volcanic hill, and the traces of which can still be seen on the uneven surface of the hillside. Interestingly the architects don't refer to the famous basalt columns (or organs) which are situated on the steep upper hillside, though they can be seen in the background of the precinct. This suggests that the designers were more influenced by topography than by the sacrality of the mountain. "The single reference point can only be the earthbound architecture of the vine (the press house and the retaining wall) as well as nature itself. Being bound to the earth as a result of the programme should be taken literally: building shall take place downwards along the gravitational principle so that the grapes are exposed only to the most necessary procedures" 16 . To sum it up: the architects had two main reference points, the traditional press house form with a gable and the topography of the hillside. They intended to reflect on both but in an abstract way.

Ironically, the reviewers revealed deeper intentions in the design. According to a reviewer, the design was inspired by the tectonics of the mountain. "The basalt wall, almost vertical at the top, halfway downwards refracts and runs to the Lake Balaton as a declivous slope. The same dynamism can be felt on the streamlined masses, following the field lines"17. His colleague has the same impressions. "The design is based on the analogy of the basalt columns, and vine-stocks grown in the soil of Badacsony"18. However, a few lines later he already mentions sacrality, more exactly the sacrality of wine-making, but he discovers it in the pure shape of the processing building. "In archaic thinking, the refinement of must into wine is the metaphor of the transformation of the 'sinful' human being into the pure son of god. In my interpretation the same holds true of the Laposa basalt wine building in Badacsony: it is also a church"19. In a third review, we find the same references: the building shapes the line of a stiffened lava. Sacrality is mentioned here twice: first, the visitors' cellar hidden under the earth, which the reviewer calls sanctuary, secondly the hill itself. The abstract, minimalist shaping of the hotel - states the reviewer - "is too profane, if we know that gods live here in the mountain"20.

In case of the Kreinbacher-St.llona Winery complex the architect - who is one of the few Hungarian designers also known abroad - approached the task theoretically. This wasn't his first commission for the winery. When explaining his earlier design, the Disznőkő Winery (Mezőzombor 1995) built on the slope of the mountain Tokaj, his starting point was the viticulture of the region, which results from the structure of the villages and which should define also the architecture itself. "The settlement here can be understood only if we understand the landscape and its cultivation" ${ }^{21}$. In the case of the winery complex under the Somló Hill, the main aim was to fit the building into the land. "The idea was not to make the buildings blend in with the other buildings in the area - which are small houses, and this, by contrast, is a huge industrial space - but with the land, as a part of it"22. The design was based on the analogy of the enlarged formations of geological forces and tectonic movements. However, the complex isn't hidden under one huge tectonic layer, 
it forms three hill-houses imitating the topology of the volcanic terrain, blending in with the environment as an artificial part of the landscape ${ }^{23}$. The analogy of lava flows running along the hill on its skirts is present also in the interior. "The overhead illumination of the underground hall is facilitated by the retaining walls and slittings that run parallel to the neighbouring fences. The holes in the interior concrete walls are reminders of the porous quality of lava tubes and basalt, which gives rise to bubble-like vaults of diverse sizes"24. The formal references of the volcanic hill appear in several forms, but the architect uses some direct formal references, too. The usual gabled roof of press houses is reflected in the cantilevered tasting room, which protrudes from the body of the artificial hill. The same shape, but in a smaller edition is repeated on the fermentation facility building, whose "bubble" windows has direct references to the champagne bubbles.

The Kreinbacher-St. Ilona Winery complex was wildly published, but with the official text for the press. Evaluations were published only in Hungarian. All reviewers appreciated the complex's close connection to the landscape. "It is not a house but a terrain feature, it is not a building but a hill" 25 . It looks like a real hill, but "in the background, we see the range of the Somló Hill, the model, so we can read the topographic shape as the enlarged version of the original" adds another reviewer ${ }^{26}$. Some reviewers reflect on the spaces between the parts of the complex, but they interpret them differently. One sees the amphitheatre created between the winery and the hotel as a volcanic crater ${ }^{27}$, while the other interprets the narrow space between the winery and the champagne cellars, like the two parts being separated by an intense gully ${ }^{28}$. The round windows are mentioned almost in every review, but they are interpreted differently: sometimes they refer to champagne bubbles, sometimes to grape berries, but they may look like a gas bubble in active lava ${ }^{29}$. The messages of the two cantilevered parts, recalling the old press houses are interpreted as intended: a reference to the neighbourhood architecture, or as a clash of tectonic and architectural character. However, the reference to the sacrality of the hill is almost missing from the reviews. A reviewer discovers a sacrality in the motive of the press house, but she adds that it is often present in new Hungarian wineries ${ }^{30}$. The most emotion is expressed by the author who involves nature into the evaluation of the complex. "The sun, earth, stone, soil, all contribute to the ripening of the wine. These forces do appear in the buildings, with radiating power, somewhere cantilevered and jutting out, just like a champagne ripening winery, elsewhere sturdily looking downward, as in the case of the cellar house of the winery" ${ }^{\prime 3}$. 


\section{CONCLUSION}

Analysing the case studies, it is clear that the design strategies are essentially the same: they copy, refer to, represent, and illustrate certain objects or phenomena outside of architecture. The landscape, the volcanic hill obviously served as an inspiration for the designers. The same inspiration, however, resulted in extremely diverse buildings being fundamentally different in their form, use of material and scale. Both of our wineries are subordinated to the landscape, though they didn't want to melt into the landscape. The architects don't intend to copy the shape of the natural landscape but reflect on it: in the hill form of the building, covered with the green roof, or in the lava-like processing building, to which rises the grape. Though most of the buildings are hidden under the earth, this is because of the technology of wine processing.

The architects of the two complexes give a detailed explanation for their design, but neither of them refers to the sacrality of the surrounding nature or place. (If somebody does so, he or she is the reviewer.) And still, sacrality is present in these complexes, thanks to the connectedness of wine and territory, terrain and landscape, which together create a harmony, an idyllic situation. As Béla Hamvas describes this mood: "At the cellars' entrance stands a huge nut tree offering cool shade even during the hottest summer. In places such as these, we could come to a standstill anywhere, sit, settle down, and say: I stay here. And, perhaps, without noticing it, it is there that death would come"32. 


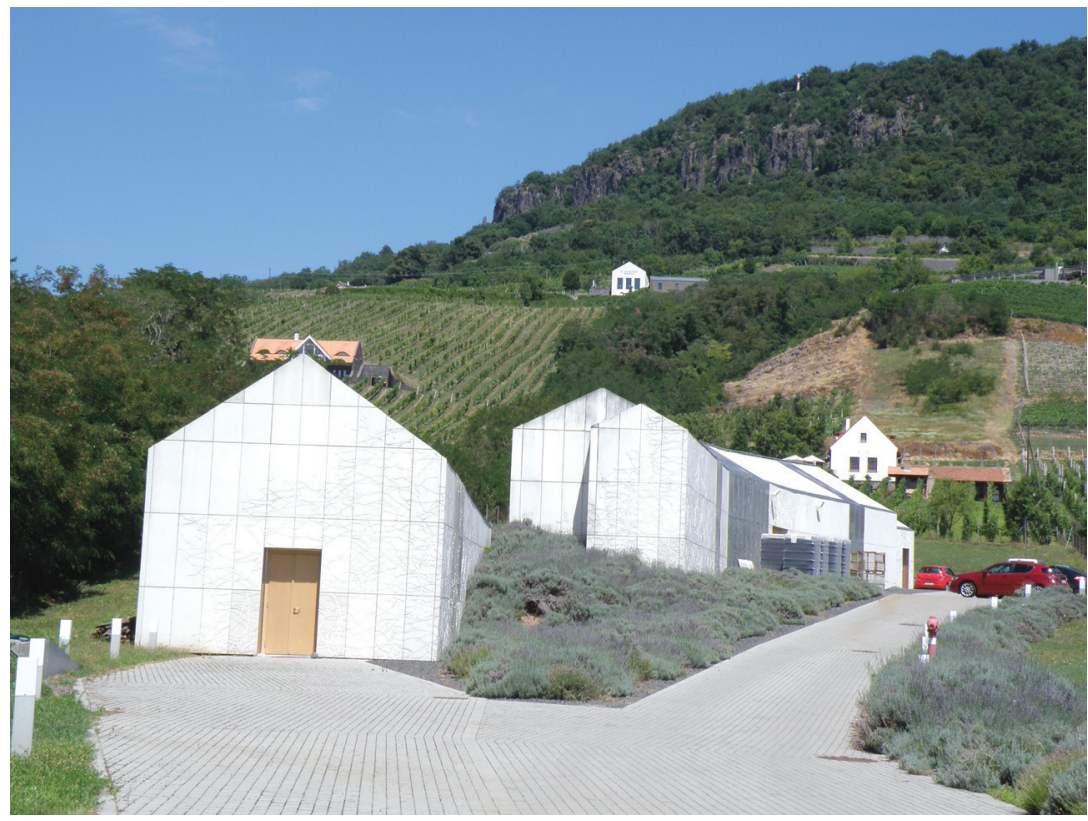

Fig. 1. View of The Bazaltbor-Laposa's winery and vine hotel, Badacsony wine district (photo by M. Simon, 2017)

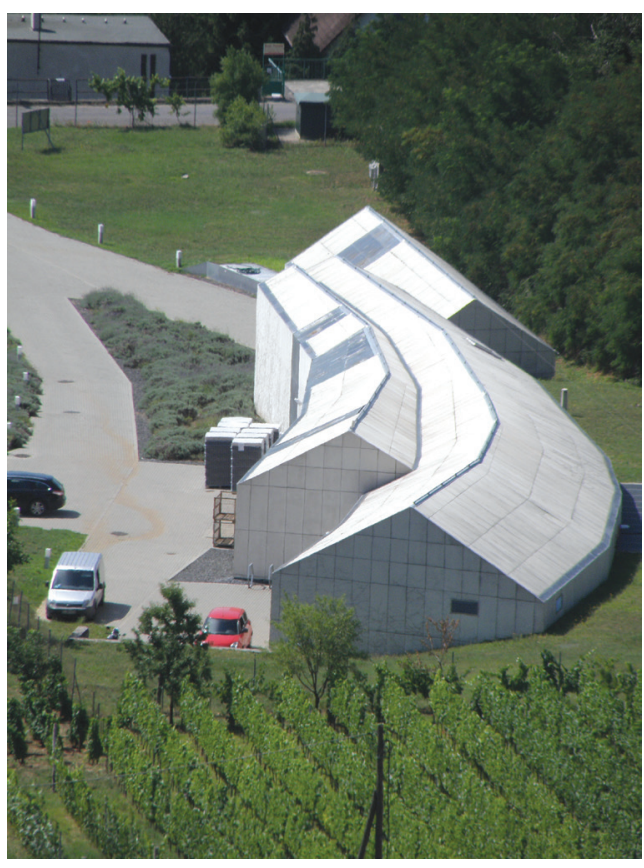

Fig. 2. View of The Bazaltbor-Laposa winery from the upper part of its site, Badacsony wine district (photo by M. Simon, 2017) 


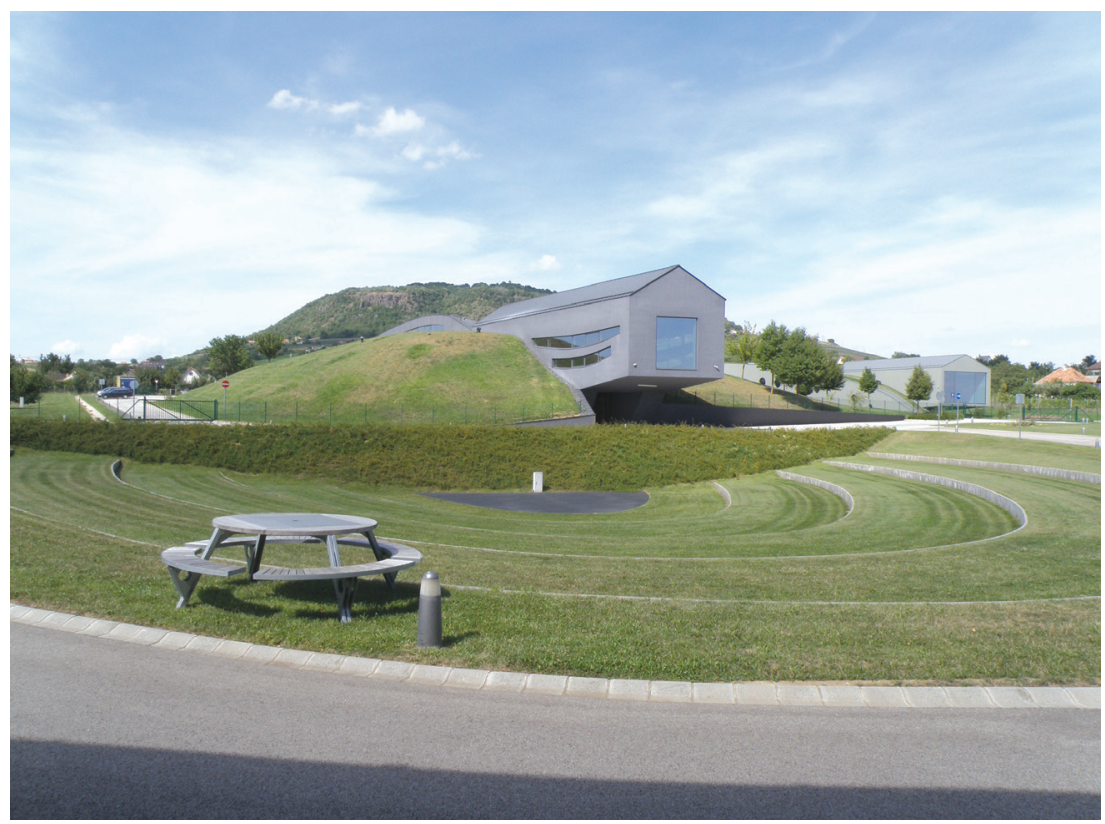

Fig. 3. View of St.llona Winery, "Greater Somló" wine district (photo by M. Simon, 2017)

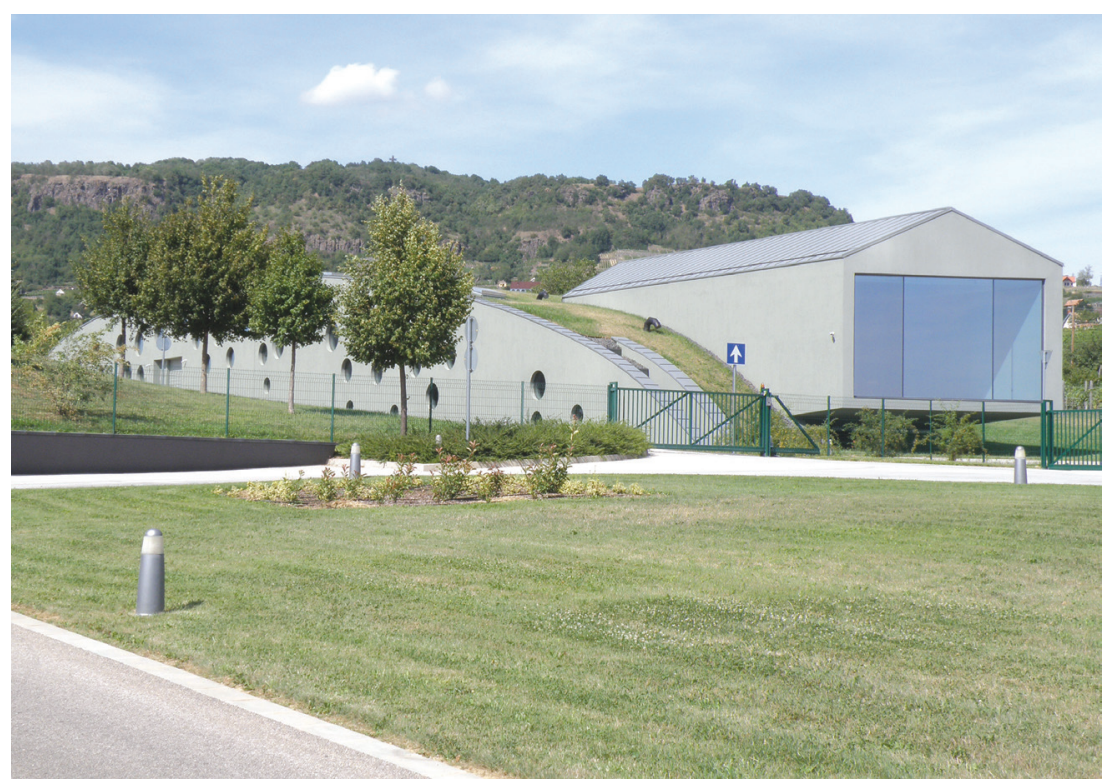

Fig. 4. View of Champagne maturing facility, "Greater Somló" wine district (photo by M. Simon, 2017) 


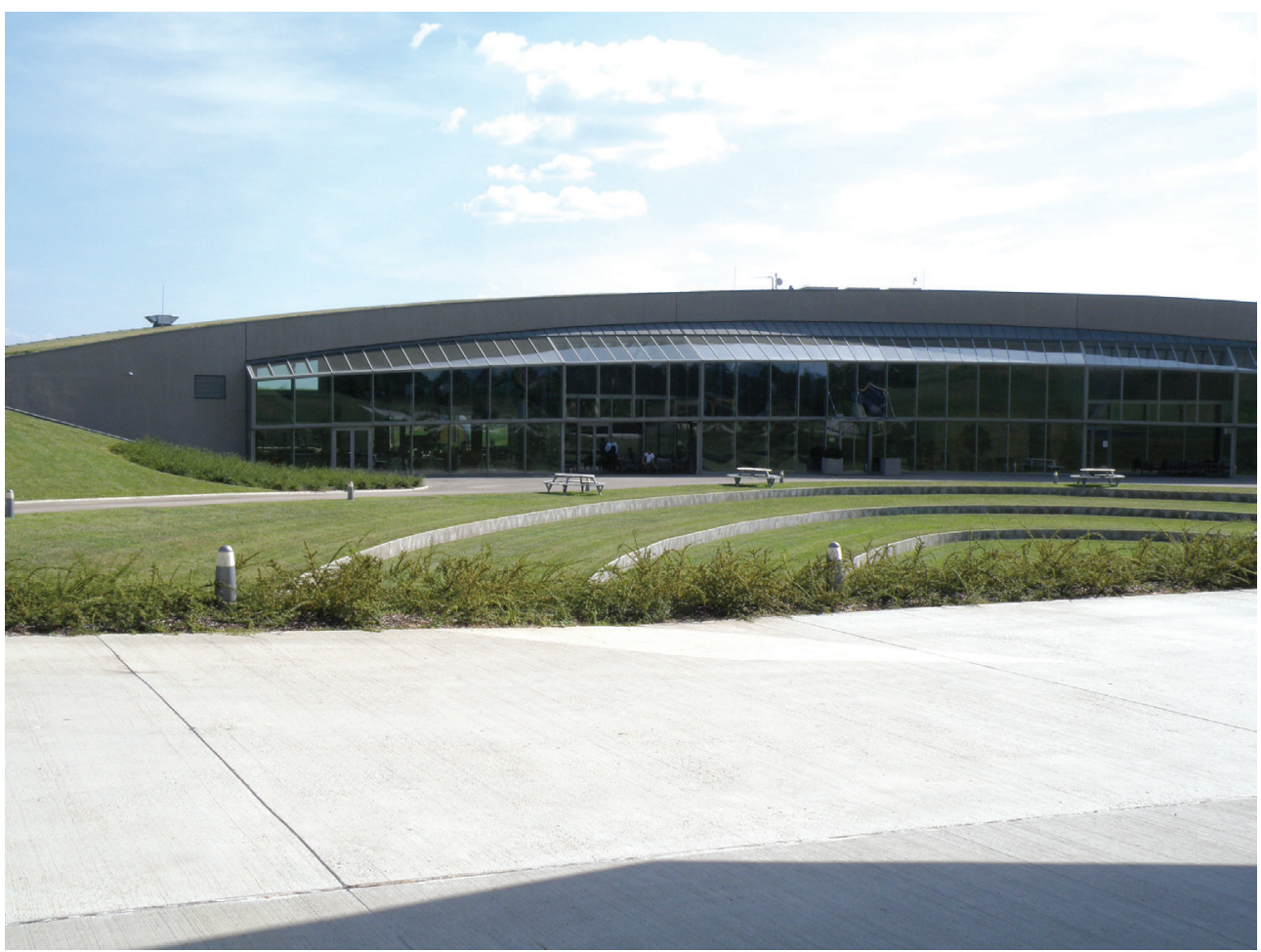

Fig. 5. View of Lodging Building, "Greater Somló" wine district (photo by M. Simon, 2017) 


\section{FOOTNOTES}

1 B. Hamvas, The Philosophy of Wine, [English translation by Csepregi, G.]. Medio Publishing House, Hungary, 2003, s. 5.

2 G. Morgan, R. Tresidder, Contemporary Wine Studies: Dancing with Bacchus, London and New York: Routledge, 2016, xiii.

3 M.L. Miklós, Book review of József Zelnik: The Great Ceremony The Wonders of Wine from Mythical Times through Dionysus to the Holy Communion, http://www.kia.hu/konyvtar/ dkiadv/szertart/ceremony_rev.htm (accessed: 14.10.2017).

4 T. Unwin, Wine and the Vine: An Historical Geography of Viticulture and the Wine Trade, The Origins of Viticulture: Symbols and Mysteries, Routledge, London and New York 2005, s. 51.

5 A French Woman's Guide to Wine, The Symbolism of Wine..."The Sacred Vine". 21. March 2015, http://winewomanworld.com/2015/03/21/the-symbolism-of-wine-the-sacred-vine/ (accessed: 14.10.2017).

6 G. Morgan and R. Tresidder, Contemporary Wine Studies: Dancing with Bacchus, Understanding the Significance of Wine, Routledge, London and New York 2016, s. 35.

7 H. Johnson, J. Robinson, The World Atlas of Wine, Mitchell Beazley London 2013, 7th edn.

8 D. Meyhöfer, O. Gollnek, P.C. Hubschmid, The Architecture of Wine: Die Architektur des Weines / L'architecture du Vin, Gingko Press, Corte Madera CA, 2000, s. 23.

9 T. Duda, Sacral Landscape and its Influence on Regional Tourism Space Development: Western Pomerania, NW Poland, International Journal of Religious Tourism and Pilgrimage, Vol. 2 (2), 2014, s. 35-49 (36).

10 Badacsony wine region, http://www.bazaltbor.hu/en/badacsony (accessed: 14.10.2017).

11 ArchDaily Building of the Year 2010, http://boty.archdaily.com/us/2010 (accessed: 14.10.2017).

12 Ekler Architect, Kreinbacher Champagne winery, http://ekler-architect.hu/en/munkak/30\# (accessed: 14.10.2017).

${ }^{13}$ Ekler Architect, Lodging Building, http://ekler-architect.hu/en/munkak/54 (accessed: 14.10.2017).

14 P. Kis, B. Molnár, Bazaltbor-Laposa pincészet: Feldolgozó épület [Bazaltbor-Laposa Winery: Processing building], Alaprajz, Vol. 17 (6), 2010, s. 66-77.

15 Laposa Winery, Archdaily.com (10 September 2010), http://www.archdaily.com/76960/ laposa-winery-atelier-peter-kis (accessed: 15.10.2017).

${ }^{16}$ Bazaltbor Laposa by Plant, Dezeen.com (7, September 2010), https://www.dezeen. com/2010/09/07/bazaltbor-badacsony-by-plant/ (accessed: 15.10.2017).

17 D. Wettstein, A kontextusába szőtt ház [A house in context], Metszet, No. 6, 2010, s. 61.

${ }^{18}$ Gy. Szegő, Oromfalas high-tech - Bazaltbor, Laposa Borászat, Badacsony [High-Tech with Gable - Bazaltbor, Laposa Winery], Régi-új Magyar Építőmúvészet, No. 4, 2011, s. 18.

19 Ibidem, s. 19. 
20 I.A. Bojár, Terroir építészet - Bazaltbor Laposa Pincészet, feldolgozó épület és borhotel, Badacsony [Terroir architecture-Bazaltbor Laposa Winery, processing building and hotel, Badacsony], Octogon, No. 7, 2010, 116.

${ }^{21}$ D. Ekler, Ember és háza. [Man and his house] Kijárat Kiadó, Budapest 2000, s. 93.

22 Idem, Házak 2000-2014. Theory and Practice. AD Reklámstúdió Kft., Budapest 2014, s. 27.

23 Ibidem, s. 93.

24 Ibidem, s. 27.

25 A. Wesselényi-Garay, Röntgenkép a „self"röl: Pezsgőérlelö, Somló [X Ray image about the self, Champagne maturing factory, Somló], Metszet, No. 6, 2013, s. 42.

${ }^{26}$ G. Széplaky, Diverzív épitészet: Ekler Dezső építészete - esztétikai perspektivából [Diverse architecture: Architecture of Dezső Ekler - from aesthetic perspective] L'Harmattan, Budapest 2016, s. 121.

27 T. Dékány, Mintabirtok a Somlón, Kreinbacher [A model domain, Kreinbacher] Bor és Piac: borpiaci szakmai magazin, No. 5-6, 2015, s. 42.

${ }^{28}$ A. Wesselényi-Garay, op. cit., s. 43.

29 Ibidem, s. 45.

39 G. Széplaky, op. cit., s. 114.

${ }^{31}$ E. Götz, A world formulated into architecture, Régi-új Magyar Építőmúvésze, No. 8, 2013, S. 5.

32 B. Hamvas, The Philosophy of Wine, [English translation by Csepregi, G.]. Medio Publishing House, Hungary, 2003, s. 41.

\section{REFERENCES}

ArchDaily Building of the Year 2010, http://boty.archdaily.com/us/2010 (accessed: 14.10.2017). A French Woman's Guide to Wine. The Symbolism of Wine..."The Sacred Vine". 21. March 2015, http://winewomanworld.com/2015/03/21/the-symbolism-of-wine-the-sacred-vine/ (accessed: 14.10.2017).

Badacsony wine region, http://www.bazaltbor.hu/en/badacsony (accessed: 14.10.2017).

Bazaltbor Laposa by Plant, Dezeen.com (7 September 2010), https://www.dezeen. com/2010/09/07/bazaltbor-badacsony-by-plant/ (accessed: 15.10.2017). 
Bojár I.A., Terroir építészet - Bazaltbor Laposa Pincészet, feldolgozó épület és borhotel, Badacsony [Terroir architecture - Bazaltbor Laposa Winery, processing building and hotel, Badacsony], Octogon, No. 7, 2010, 116.

Dékány T., Mintabirtok a Somlón, Kreinbacher [A model domain, Kreinbacher] Bor és Piac: borpiaci szakmai magazin, No. 5-6, 2015, 40-43.

Duda T., Sacral Landscape and its Influence on Regional Tourism Space Development: Western Pomerania, NW Poland, International Journal of Religious Tourism and Pilgrimage, Vol. 2 (2), 2014, 35-49.

Ekler Architect, Kreinbacher Champagne winery, http://ekler-architect.hu/en/munkak/30\# (accessed: 14.10.2017).

Ekler Architect, Lodging Building, http://ekler-architect.hu/en/munkak/54 (accessed: 14.10.2017). Ekler D., Ember és háza. [Man and his house] Kijárat Kiadó, Budapest 2000.

Ekler D., Házak 2000-2014. AD Reklámstúdió Kft., Budapest 2014.

Götz E., A world formulated into architecture, Régi-új Magyar Építőművészet, No. 8, 2013, 4-7. Hamvas B., A bor filozófiája. [The Philosophy of Wine, English translation by Csepregi, G.], Medio Publishing House, Hungary, 2003.

Johnson H. and Robinson J., The World Atlas of Wine, Mitchell Beazley, London 2013, 7th edn. Kis P., and Molnár B., Bazaltbor-Laposa pincészet: Feldolgozó épület [Bazaltbor-Laposa Winery: Processing building], Alaprajz, Vol. 17 (6), 2010, 66-77.

Laposa Winery, Archdaily.com (10 September 2010), http://www.archdaily.com/76960/ laposa-winery-atelier-peter-kis (accessed: 15.10.2017).

Meyhöfer D., Gollnek O., and Hubschmid P. C., The Architecture of Wine: Die Architektur des Weines / L'architecture du Vin, Gingko Press, Corte Madera CA, 2000.

MorganG. and Tresidder R., Contemporary Wine Studies: Dancing with Bacchus, Routledge, London and New York 2016.

Szegő Gy., Oromfalas high-tech - Bazaltbor, Laposa Borászat, Badacsony, [High-Tech with Gable - Bazaltbor, Laposa Winery], Régi-új Magyar Építőművészet, No. 4, 2011, 14-19.

Széplaky G., Diverziv épitészet: Ekler Dezső épitészete - esztétikai perspektivából [Diverse architecture: Architecture of Dezső Ekler - from aesthetic perspective] L'Harmattan, Budapest 2016.

Wesselényi-Garay A., Röntgenkép a „self"ről: Pezsgőérlelö, Somló [X Ray image about the self, Champagne maturing factory, Somló], Metszet, No. 6, 2013, 40-45.

Wettstein D., A kontextusába szőtt ház [A house in context], Metszet, No. 6, 2010, 61.

ADRES BIBLIOGRAFICZNY ARTYKUŁU: Harea O., Simon M., Wineries in communication with holy mountains, Przestrzeń/Urbanistyka/ Architektura, 1/2018, s. 147-162.

DATA AKCEPTACJI OSTATECZNEJ WERSII DO OPUBLIKOWANIA: 15.06.2018. 